\title{
Association study between single nucleotide polymorphisms in leptin and growth traits in Cyprinus carpio var. Jian
}

\author{
Y. Tang, H. Li, J. Li, F. Yu and J. Yu
}

Key Laboratory of Freshwater Fisheries and Germplasm Resources Utilization, Ministry of Agriculture, Freshwater Fisheries Research Center, Chinese Academy of Fishery Sciences, Wuxi, China

Corresponding author: J. Yu

E-mail: yujh@ffrc.cn

Genet. Mol. Res. 15 (3): gmr.15037635

Received September 15, 2015

Accepted January 15, 2016

Published August 5, 2016

DOI http://dx.doi.org/10.4238/gmr.15037635

Copyright (C) 2016 The Authors. This is an open-access article distributed under the terms of the Creative Commons Attribution ShareAlike (CC BY-SA) 4.0 License

ABSTRACT. Leptin is a hormone that affects the regulation of body weight, energy expenditure, fat metabolism, food intake, and appetite. In this study, we cloned the $j I L E P-A 1$ and $j l L E P-A 2$ genes in Jian carp (Cyprinus carpio var. Jian) and performed an association analysis between identified polymorphisms and growth traits. Three polymorphisms in exons of jlLEP-A1 (A1-T113C) and jlLEP-A2 (A2-G415A and A2-G427A) were identified, and genotyped by the polymerase chain reaction - restriction fragment length polymorphism method in 263 female and 294 male Jian carp. All three SNPs were missense mutations. Association analysis revealed that the three SNPs were significantly associated with growth traits in male Jian carp. Only SNP A1-T113C was significantly associated with growth traits in female Jian carp. Analysis of diplotypes derived from $j l L E P-A 2$ SNPs revealed an association with growth traits in male but not female Jian 
carp. These results demonstrate that polymorphisms in the leptin gene are associated with growth traits and may be used for marker-assisted selection programs in Jian carp breeding and production.

Key words: Leptin; Single nucleotide polymorphisms; Growth traits; Cyprinus carpio var. Jian

\section{INTRODUCTION}

Leptin, a product of the obese (ob) gene, is a cytokine that was first discovered in mouse by Zhang et al. (1994). In mammals, leptin is involved in a diverse range of physiological functions, including appetite and body weight regulation, bone remodeling, fat metabolism, immune responses, and reproduction (Houseknecht et al., 1998; Moschos et al., 2002; Mácajová et al., 2004; Roubos et al., 2012). In fish, the function of leptin remains unclear, although several studies have been conducted on fish leptin genes. The first leptin-like gene was identified in the pufferfish (Takifugu rubripes) using syntenic gene analysis (Kurokawa et al., 2005). Leptin genes have subsequently been cloned from other teleost species, including common carp (Cyprinus carpio) (Huising et al., 2006), zebrafish (Danio rerio) (Gorissen et al., 2009), medaka (Oryzias latipes) (Kurokawa and Murashita, 2009), grass carp (Ctenopharyngodon idella) (Li et al., 2010), rainbow trout (Oncorhynchus mykiss) (Murashita et al., 2008), Atlantic salmon (Salmo salar) (Rønnestad et al., 2010; Angotzi et al., 2013), yellow catfish (Pelteobagrus fulvidraco) (Gong et al., 2013), orange-spotted grouper (Epinephelus coioides) (Zhang et al., 2013), and Jian carp (Cyprinus carpio var. Jian) (Tang et al., 2013). Unlike most vertebrates, which possess a single copy of leptin, several teleost fish have duplicate leptin genes, including zebrafish, Japanese medaka, Atlantic salmon, orange-spotted grouper, and Jian carp. Type A leptin was found to be present in the majority of species studied. In Jian carp, jlLEP-A1 and jlLEP-A2 are expressed in a wide range of tissues, which suggests that leptin-A may have pleiotropic physiological effects (Tang et al., 2013).

Advances in molecular genetics have led to the identification of DNA polymorphisms that affect traits of interest in animals. Analysis of single nucleotide polymorphisms (SNPs) have been increasingly utilized in various genetic disciplines, particularly in marker-assisted selection (MAS) programs. Several association studies of SNPs in the leptin gene with growth traits in farmed animals have been published, especially in chicken (Sadeghi et al., 2012), swine (Pérez-Montarelo et al., 2012), cattle (da Silva et al., 2012), and fox (Zhang and Bai, 2015). In teleost fish, however, only the studies of Wei et al. (2013) and Huang et al. (2014) have reported polymorphisms in the orange-spotted grouper (Epinephelus coioides) leptin-a gene and their associations with growth traits.

Jian carp (Cyprinus carpio var. Jian) was first bred artificially at the Freshwater Fisheries Research Center of the Chinese Academy of Fishery Sciences (FFRC, CAFS) and is now widely cultured in China. Leptin is a potential candidate gene that influences growth traits in Jian carp; therefore, the objectives of this study were to investigate polymorphisms in the leptin gene and to explore the relationship between genotypes and growth traits. The results of this study may provide a basis for MAS programs aiming to improve growth traits and preserve important genetic resources.

Genetics and Molecular Research 15 (3): gmr.15037635 


\section{MATERIAL AND METHODS}

\section{Animals and phenotypic data}

A total of 557 (female 263; male 294) samples comprising 12 full-sibling families were used, which were created by crossing 12 sires and 12 dams from Yixing Breeding Base at the Freshwater Fisheries Research Center of the Chinese Academy of Fishery Sciences (Wuxi, China). The offspring were cultured in different cages for the first month. About 50 individuals per family were randomly selected, passive integrated transponder (PIT) tagged, and mixed in the same pond when the fish reached $\sim 25 \mathrm{~g}$ in weight. Considering that the growth rate differs between the juvenile and adult stages, the body weight gain (BWG) was measured during the two developmental stages respectively. The BWG of the juvenile and adult stages in Jian carp was defined by subtracting the initial BW from juvenile BW, and juvenile BW from adult BW, respectively. All animal experiments complied with the Guidelines for the Care and Use of Laboratory Animals of Jiangsu Province, China.

\section{PCR amplification and SNP discovery}

Blood samples $(0.5 \mathrm{~mL}$ each) were collected from the tail vein of each animal using disposable syringes containing the anticoagulant citrate-dextrose. Genomic DNA was extracted using a Blood Genome DNA extraction Kit (Takara, Dalian, China), following the manufacturer recommendation. The concentration of genomic DNA was determined using a UV spectrophotometer.

To discover putative SNPs in $j l L E P-A 1$ and $j l L E P-A 2$, DNA samples from eight unrelated Jian carp parents were selected. Nucleotide sequences of the primers and restriction enzymes used are shown in Table 1 . PCR was performed in a $12.5-\mu \mathrm{L}$ reaction volume containing 100-200 ng genomic DNA using HotStar Taq (Takara, Dalian, China). The thermal cycle consisted of $3 \mathrm{~min}$ initial denaturation at $94^{\circ} \mathrm{C}, 30$ cycles of $30 \mathrm{~s}$ at $94^{\circ} \mathrm{C}, 30 \mathrm{~s}$ at $56-$ $58^{\circ} \mathrm{C}$, and $1 \mathrm{~min}$ at $72^{\circ} \mathrm{C}$, followed by a $5 \mathrm{~min}$ final extension at $72^{\circ} \mathrm{C}$. The $j l L E P-A 1$ and $j l L E P-A 2$ genes were cloned as previously described (Tang et al., 2013). The sequences were aligned by the Clustal X program to identify potential SNPs. Nucleotide sites that contained an alternative base in two or more individuals were considered putative SNP loci.

Table 1. Primers, restriction enzymes, and restriction fragments of leptin SNPs.

\begin{tabular}{l|l|l|l}
\hline Locus & Primers & Restriction enzyme $(\mathrm{T})$ & Fragments $(\mathrm{bp})$ \\
\hline $\mathrm{A} 1-\mathrm{T} 113 \mathrm{C}$ & $j l L E P-A 1-1 \mathrm{~F}:$ CTGCACTGGTGCCAAGTTTAA & BseGI $\left(55^{\circ} \mathrm{C}\right)$ & TT: 333 \\
\hline & $j l L E P-A 1-1 \mathrm{R}:$ ACCTCAGGGTAAAGTTCTGGATC & & CC: 109,224 \\
\hline A2-G415A & $j l L E P-A 2-1 \mathrm{~F}: C C A C T T C A A A A G G G A C A A A T A T G T A C C$ & $X a g \mathrm{I}\left(37^{\circ} \mathrm{C}\right)$ & AA: 792 \\
\hline & $j l L E P-A 2-1 \mathrm{R}: C T T G A A A A T C C T C T T G G C C T C G A C T$ & & GG: 382,410 \\
\hline A2-G427A & $j l L E P-A 2-2 \mathrm{~F}: C C A C T T C A A A A G G G A C A A A T A T G T A C C$ & AluI $\left(37^{\circ} \mathrm{C}\right)$ & GG: 181 \\
\hline & $j l L E P-A 2-2 \mathrm{R}: C T T G A A A A T C C T C T T G G C C T C G A C T$ & & AA: 129,52 \\
\hline
\end{tabular}

\section{SNP genotyping}

The SNPs in $j l L E P-A 1$ and $j l L E P-A 2$ were genotyped using the polymerase chain reaction - restriction fragment length polymorphism (PCR-RFLP) method. Pairs of primers were designed using Primer Premier 5 software. Restriction enzymes (Thermo, USA), 
including BseG I, Xag I, and Alu I, were selected based on the mutation sites. The amplification products were completely digested in a $10-\mu \mathrm{L}$ reaction solution containing $6 \mu \mathrm{L}$ PCR products and $0.1 \mu \mathrm{L}$ enzyme at the appropriate temperature for $1-2 \mathrm{~h}$. The genotypes of samples were identified by $2 \%$ agarose gel electrophoresis.

\section{Statistical analysis}

Allele and genotype frequencies were calculated using a simple allele counting method. Hardy-Weinberg equilibrium was tested for goodness-of-fit by comparing expected and observed genotype frequencies using a Chi-square test (Rodriguez et al., 2009). Association analysis between genotypes of SNPs in leptin and growth traits was performed using the general linear model (GLM) procedure with SPSS 15.0 software. We used the following statistical model: $Y=u+G+e$ where, $Y$ is the phenotypic value of a growth trait; $\mathrm{u}$ is population mean value of growth traits, G is the fixed genotype effect of each SNP, and $\mathrm{e}$ is the random error effect. Multiple comparisons between different genotypes were tested using the least significant difference (LSD) method. $\mathrm{P}<0.05$ was considered as statistically significant and $\mathrm{P}<0.01$ was considered as extremely significant.

\section{RESULTS}

\section{Identification and genotyping of SNPs}

The DNA sequence of $j l L E P-A 1$ (GenBank accession No. KC496017) and jlLEP-A2 (GenBank accession No. KC496018) were 741- and 792-bp long, respectively. jlLEP-A1 and jlLEP-A2 contained an intron of 93 and $102 \mathrm{bp}$, respectively, and both contained an open reading frame (ORF) of $516 \mathrm{bp}$, which encoded a 171-amino acid protein. Five SNPs were identified by the alignment of $j l L E P-A 1$ and $j l L E P-A 2$ fragments from eight individuals. Two SNPs ( $j l L E P$ $A 1-\mathrm{G} 533 \mathrm{~A}, j l L E P-A 2-\mathrm{G} 360 \mathrm{~A})$ out of five were not analyzed because there was no available restriction enzyme for RFLP genotyping. Therefore, the three SNPs in exons of $j l L E P-A 1$ (A1-T113C) and $j l L E P-A 2$ (A2-G415A and A2-G427A) were examined. All three SNPs were missense mutations. There was a $\mathrm{T} / \mathrm{C}$ substitution at position $113 \mathrm{bp}$ of the $j l L E P-A 1$ gene, which replaced serine with proline, and a G/A substitution at 415 and $427 \mathrm{bp}$ of the jlLEP-A2 gene, which each replaced arginine with lysine. Three SNPs were genotyped by PCR-RFLP in 263 female and 294 male Jian carp. Enzyme digested products of A1-T113C, A2-G415A, and A2G427A SNPs in partial samples are shown in Figure 1A, B, and C, respectively.

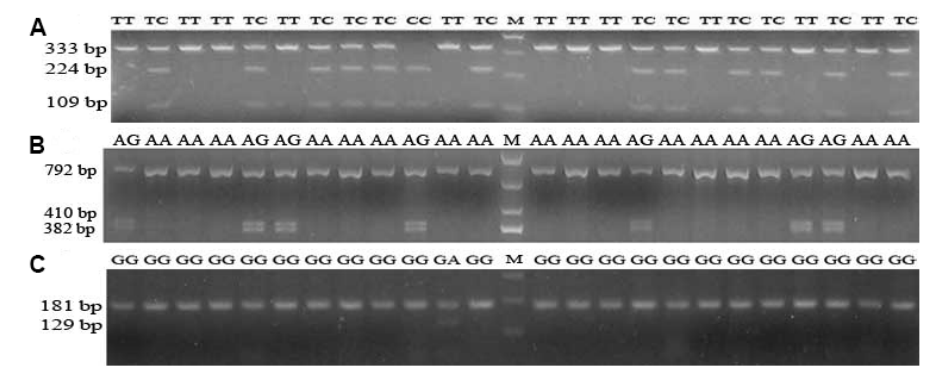

Figure 1. Digestion production of three SNPs. A. A1-T113C by BseGI; B. A2-G415A by XagI; C. A2-G427A by AluI.

Genetics and Molecular Research 15 (3): gmr.15037635 
At locus A2-G427A, there were only two genotypes (GG and GA). Exact tests showed that one locus (A1-T113C) deviated significantly from Hardy-Weinberg equilibrium $(\mathrm{P}<0.05)$ in the test population of Jian carp. At locus A1-T113C, the frequency of the TT genotype (53.6\%) was higher than that of the TC genotype (43.3\%) in female Jian carp, while the opposite was true in male Jian carp. At locus A2-G415A, the frequency of the AA genotype $(61.660 .9 \%)$ was higher than that of the GG genotype (3.0/3.4\%) in female and male Jian carp. At locus A2-G427A, the G allele occurred significantly more frequently (96.697.8\%) than allele A, and the frequency of the GG genotype (93.2/95.6\%) was higher than that of the GA genotype (6.8/4.4\%) in female and male Jian carp (Table 2).

Table 2. Frequencies of genotypes and alleles of three SNPs of leptin in female and male Jian carp.

\begin{tabular}{|c|c|c|c|c|c|c|c|}
\hline \multirow{3}{*}{$\begin{array}{l}\text { Locus } \\
\text { A1-T113C }\end{array}$} & \multirow{3}{*}{$\frac{\text { Sample size (female/male) }}{263 / 294}$} & \multicolumn{3}{|c|}{ Genotype frequencies [female/male (\%)] } & \multicolumn{2}{|c|}{ Allele frequencies [female/male (\%)] } & \multirow{3}{*}{$\begin{array}{l}\mathrm{P}(\text { female } / \mathrm{male}) \\
0.007^{*} / 4.2 \mathrm{E}-07^{*}\end{array}$} \\
\hline & & TT & TC & $\mathrm{CC}$ & $\mathrm{T}$ & $\mathrm{C}$ & \\
\hline & & $53.6 / 46.6$ & $43.3 / 51.7$ & $3.1 / 1.7$ & $75.3 / 72.4$ & $24.7 / 27.6$ & \\
\hline \multirow[t]{2}{*}{ A2-G415A } & \multirow[t]{2}{*}{$263 / 294$} & AA & $\mathrm{AG}$ & GG & A & $\mathrm{G}$ & \multirow[t]{2}{*}{$0.216 / 0.252$} \\
\hline & & $61.6 / 60.9$ & $35.4 / 35.7$ & $3.0 / 3.4$ & $79.3 / 78.7$ & $20.7 / 21.3$ & \\
\hline \multirow[t]{2}{*}{ A2-G427A } & \multirow[t]{2}{*}{$263 / 294$} & GG & GA & AA & $\mathrm{G}$ & A & \multirow[t]{2}{*}{$0.566 / 0.698$} \\
\hline & & $93.2 / 95.6$ & $6.8 / 4.4$ & $0 / 0$ & $96.6 / 97.8$ & $3.4 / 2.2$ & \\
\hline
\end{tabular}

*Significant at the $\mathrm{P}<0.05$ level.

\section{Haplotype and diplotype analysis}

Based on genotype data for jlLEP-A2 (A2-G415A and A2-G427A) SNPs, four haplotypes were found in the Jian carp population, the frequencies of which are summarized in Table 3. Haplotype 1, which is the most common haplotype, had an estimated frequency of 0.761/0.778 in female and male Jian carp. Another common haplotype, haplotype 3, occurred only at a frequency of $0.203 / 0.200$ in female and male Jian carp. The two common diplotypes, $\mathrm{H} 1 \mathrm{H} 1$ and $\mathrm{H} 1 \mathrm{H} 3$, composed of haplotype 1 and 3, respectively, accounted for 89.7 and $92.5 \%$ of all diplotypes in female and male Jian carp (Table 4). Only one male Jian carp with the diplotype $\mathrm{H} 3 \mathrm{H} 4$ was deleted in the following association analysis.

Table 3. Pattern and frequency of each reconstructed haplotype in the genotyped female and male population. The individual alleles for each haplotype are given in the order A2-G415A and A2-G427A.

\begin{tabular}{l|c|c|c|c}
\hline & $\mathrm{H} 1$ & $\mathrm{H} 2$ & $\mathrm{H} 3$ & $\mathrm{H} 4$ \\
\hline Haplotype & $\mathrm{AG}$ & $\mathrm{AA}$ & $\mathrm{GG}$ & $\mathrm{GA}$ \\
\hline Frequency (female/male) & $0.761 / 0.778$ & $0.032 / 0.010$ & $0.203 / 0.200$ & $0.004 / 0.012$ \\
\hline
\end{tabular}

Table 4. Frequency of each reconstructed diplotype in the haplotyped female and male population.

\begin{tabular}{l|c|c|c|c|c|c}
\hline Diplotype & $\mathrm{H} 1 \mathrm{H} 1$ & $\mathrm{H} 1 \mathrm{H} 3$ & $\mathrm{H} 1 \mathrm{H} 2$ & $\mathrm{H} 3 \mathrm{H} 3$ & $\mathrm{H} 1 \mathrm{H} 4$ & $\mathrm{H} 3 \mathrm{H} 4$ \\
\hline Frequency (female/male) & $0.570 / 0.595$ & $0.327 / 0.330$ & $0.046 / 0.01$ & $0.030 / 0.031$ & $0.027 / 0.027$ & $0 / 0.003$ \\
\hline
\end{tabular}

\section{Association of SNPs and diplotypes of SNPs with growth traits}

Associations of leptin gene polymorphisms with growth traits were analyzed by oneway ANOVA in SPSS 15.0 software. The results are shown in Tables 5 and 6 . All three single SNPs (A1-T113C, A2-G415A, and A2-G427A) showed significant or extremely significant 
associations with growth traits in male Jian carp. Only one SNP (A1-T113C) was significantly or extremely significantly associated with growth traits in female Jian carp. Diplotype-based analysis indicated that five diplotypes were significantly associated with growth traits in male Jian carp.

Table 5. Association of SNPs with body weight gain in male and female Jian carp.

\begin{tabular}{|c|c|c|c|c|}
\hline Locus & Genotype & Juvenile stage & Adult stage & Sample size \\
\hline \multicolumn{5}{|l|}{ Male Jian carp } \\
\hline \multirow[t]{3}{*}{ A1-T113C } & TC & $100.38 \pm 1.70$ & $683.80 \pm 10.63^{\mathrm{a}}$ & 152 \\
\hline & TT & $96.61 \pm 2.39$ & $652.28 \pm 11.18^{b}$ & 137 \\
\hline & $\mathrm{CC}$ & $98.84 \pm 10.28$ & $690.12 \pm 46.54^{\mathrm{ab}}$ & 5 \\
\hline \multirow[t]{3}{*}{ A2-G415A } & AA & $99.60 \pm 1.75^{\mathrm{a}}$ & $670.27 \pm 9.18^{\mathrm{A}}$ & 179 \\
\hline & $\mathrm{AG}$ & $98.64 \pm 5.60^{\mathrm{a}}$ & $679.34 \pm 13.86^{\mathrm{A}}$ & 105 \\
\hline & GG & $80.26 \pm 3.36^{b}$ & $544.11 \pm 31.12^{\mathrm{B}}$ & 10 \\
\hline \multirow[t]{2}{*}{ A2-G427A } & GG & $99.30 \pm 1.47^{\mathrm{a}}$ & $671.52 \pm 7.94^{\mathrm{a}}$ & 281 \\
\hline & GA & $83.46 \pm 4.02^{b}$ & $619.41 \pm 16.51^{b}$ & 13 \\
\hline \multicolumn{5}{|l|}{ Female Jian carp } \\
\hline \multirow[t]{3}{*}{ A1-T113C } & $\mathrm{TC}$ & $110.41 \pm 2.24^{\mathrm{A}}$ & $828.89 \pm 14.27^{\mathrm{a}}$ & 114 \\
\hline & TT & $103.30 \pm 2.33^{\mathrm{AB}}$ & $787.82 \pm 12.98^{b}$ & 141 \\
\hline & $\mathrm{CC}$ & $83.44 \pm 6.02^{\mathrm{B}}$ & $757.66 \pm 50.12^{\mathrm{ab}}$ & 8 \\
\hline
\end{tabular}

Data are reported as means \pm SE. Different capital letters in the same column show extremely significant differences $(\mathrm{P}<0.01)$; different small letters in the same column show significant differences $(\mathrm{P}<0.05)$.

Table 6. Association of diplotypes with body weight gain in male Jian carp.

\begin{tabular}{l|c|c|c}
\hline Diplotype & Juvenile stage & Adult stage & Frequency \\
\hline $\mathrm{H} 1 \mathrm{H} 1$ & $99.93 \pm 1.77^{\mathrm{a}}$ & $670.20 \pm 9.37^{\mathrm{ab}}$ & 175 \\
\hline $\mathrm{H} 1 \mathrm{H} 3$ & $99.98 \pm 2.77^{\mathrm{b}}$ & $686.54 \pm 14.72^{\mathrm{a}}$ & 97 \\
\hline $\mathrm{H} 3 \mathrm{H} 3$ & $79.69 \pm 3.70^{\mathrm{c}}$ & $535.34 \pm 33.39^{\mathrm{c}}$ & 8 \\
\hline $\mathrm{H} 1 \mathrm{H} 4$ & $82.40 \pm 2.41^{\mathrm{bc}}$ & $591.96 \pm 15.35^{\mathrm{bc}}$ & 4 \\
\hline $\mathrm{H} 1 \mathrm{H} 2$ & $85.10 \pm 13.45^{\mathrm{abc}}$ & $673.40 \pm 31.13^{\mathrm{abc}}$ & \\
\hline
\end{tabular}

Different lowercase letters in the same column represent a significant difference $(\mathrm{P}<0.05)$.

When specimens were assigned to three groups based on their genotype at the A1T113C locus, the group with the TC genotype performed significantly better for BWG than did the other groups (CC and TT) at the juvenile and adult stages. However, this difference was not observed in the male juvenile stage.

At the A2-G415A locus, males who inherited the GG genotype were significantly inferior for BWG compared to those who inherited the AA or AG genotypes at both the juvenile and adult stages; however, there was no significant difference among genotypes in females. At the A2-G427A locus, BWG was significant only in males, for which the GG group showed significantly better performance than the GA group. No difference was observed for this trait in females at this locus.

Male Jian carps possessing $\mathrm{H} 1 \mathrm{H} 3$ had the highest values for growth traits, while those with $\mathrm{H} 3 \mathrm{H} 3$ had the lowest values for growth traits. At the juvenile stage, the growth traits of Jian carp with $\mathrm{H} 1 \mathrm{H} 1$ had significantly higher values than those of Jian carp with $\mathrm{H} 3 \mathrm{H} 4$ and $\mathrm{H} 1 \mathrm{H} 4$. However, the growth traits of Jian carp with $\mathrm{H} 1 \mathrm{H} 3$ were significantly higher than those with $\mathrm{H} 3 \mathrm{H} 4$ and $\mathrm{H} 1 \mathrm{H} 4$.

\section{DISCUSSION}

In the present study, one SNP and two SNPs were found in $j l L E P-A l$ and $j l L E P-A 2$, 
respectively. The three SNPs could be successfully genotyped by the PCR-RFLP method. There are always two paralogues genes with high sequence similarity within the Jian carp genome; therefore, it is difficult to find and identity SNPs between the two paralogous genes. When SNPs exists in AT rich regions, it is clear that appropriate primers cannot be designed by the PCR-RFLP method. SNPs should be widely used in fish breeding with other methods of detection such as tetra-primer PCR method and the amplification refractory mutation system (tetra-primers ARMS) (Ye et al., 2001) and intron-primed exon-crossing (IPEC) (Ryynänen and Primmer, 2006).

Several studies have showed that introns span a much larger portion of the genome than exons (Venter et al., 2001), and introns are usually more highly diversified than adjacent exons (Özlem and Dursum, 2011). As a result, introns include more polymorphisms than exons. However, all three SNPs identified in the present study existed in leptin exons and were missense mutations. There were no significant differences in phenotypic characterization, which implies that the mutated amino acids were not essential and did not change the function of leptin.

Leptin polymorphisms may have an effect on growth traits in animal husbandry. Yang et al. (2007) reported that leptin may be a candidate gene for growth traits such as height at hip cross and was applied to MAS in Chinese cattle breeds. Kulig and Kmieć (2009) showed that the average daily weight gain between 3 and 210 days of age was significantly higher in Limousin cattle possessing the $\mathrm{CT} / \mathrm{CT}$ haplotype compared with those possessing the $\mathrm{CC} / \mathrm{CC}$ and $\mathrm{CC} / \mathrm{CT}$ haplotypes for the A59V polymorphism in exon 3 of the leptin gene. Clempson et al. (2011) discovered that four leptin SNPs (A1457G, A59V, UASMS1, UASMS2) were associated with different types of growth performance in Holstein cows. Recently, Wei et al. (2013) reported that several polymorphisms in the leptin- $a$ gene are associated with growth traits and can be used for MAS in orange-spotted grouper populations. In conclusion, these reports have revealed that the leptin gene may be an important candidate gene associated with growth traits.

Single SNP analysis is a traditional tool in MAS. Recently, haplotypes and/or diplotype analysis has gradually been used to elucidate the relationships between candidate gene polymorphisms and economical traits (Zuo et al., 2014). The results of our study clearly demonstrate that one and three SNPs were significantly and extremely significantly associated with growth traits in female and male Jian carp, respectively. Diplotype analysis derived from two SNPs showed that these were only associated with growth traits in male Jian carp. Jian carp with $\mathrm{H} 1 \mathrm{H} 1$ and $\mathrm{H} 1 \mathrm{H} 3$ had higher values for growth traits than those with other diplotypes. However, Jian carp with $\mathrm{H} 3 \mathrm{H} 3$ had the lowest values for growth traits in five diplotypes. These results suggest that the $\mathrm{H} 1$ and $\mathrm{H} 3$ haplotypes may have positive and negative effects on growth traits, respectively. Growth traits could be ultimately affected by the interaction of SNPs. Leptin SNPs could be applied as useful genetic markers in future Jian carp breeding programs.

Growth is a typical quantitative trait controlled by multiple genes. It is necessary to detect more polymorphisms in other growth-related genes and to evaluate major effects of single and combined gene markers. The results of these kinds of studies will be of importance to MAS in fish.

\section{Conflicts of interest}

The authors declare no conflict of interest.

Genetics and Molecular Research 15 (3): gmr.15037635 


\section{ACKNOWLEDGMENTS}

Research supported by the Natural Science Foundation of Jiangsu Province (\#BK20141096), the National Technology System for Conventional Freshwater Fishery Industry (\#CARS-46), and the Special Research Fund at Central Nonprofit Research Institutes (\#2015JBFM10).

\section{REFERENCES}

Angotzi AR, Stefansson SO, Nilsen TO, Rathore RM, et al. (2013). Molecular cloning and genomic characterization of novel leptin-like genes in salmonids provide new insight into the evolution of the Leptin gene family. Gen. Comp. Endocrinol. 187: 48-59. http://dx.doi.org/10.1016/j.ygcen.2013.03.022

Clempson AM, Pollott GE, Brickell JS, Bourne NE, et al. (2011). Evidence that leptin genotype is associated with fertility, growth, and milk production in Holstein cows. J. Dairy Sci. 94: 3618-3628. http://dx.doi.org/10.3168/jds.2010-3626

da Silva RC, Ferraz JB, Meirelles FV, Eler JP, et al. (2012). Association of single nucleotide polymorphisms in the bovine leptin and leptin receptor genes with growth and ultrasound carcass traits in Nellore cattle. Genet. Mol. Res. 11:37213728. http://dx.doi.org/10.4238/2012.August.17.10

Gong Y, Luo Z, Zhu QL, Zheng JL, et al. (2013). Characterization and tissue distribution of leptin, leptin receptor and leptin receptor overlapping transcript genes in yellow catfish Pelteobagrus fulvidraco. Gen. Comp. Endocrinol. 182: 1-6. http://dx.doi.org/10.1016/j.ygcen.2012.11.006

Gorissen M, Bernier NJ, Nabuurs SB, Flik G, et al. (2009). Two divergent leptin paralogues in zebrafish (Danio rerio) that originate early in teleostean evolution. J. Endocrinol. 201: 329-339. http://dx.doi.org/10.1677/JOE-09-0034

Houseknecht KL, Baile CA, Matteri RL and Spurlock ME (1998). The biology of leptin: a review. J. Anim. Sci. 76: 14051420.

Huang H, Wei Y, Meng Z, Zhang Y, et al. (2014). Polymorphisms of leptin-b gene associated with growth traits in orangespotted grouper (Epinephelus coioides). Int. J. Mol. Sci. 15: 11996-12006. http://dx.doi.org/10.3390/ijms150711996

Huising MO, Geven EJ, Kruiswijk CP, Nabuurs SB, et al. (2006). Increased leptin expression in common Carp (Cyprinus carpio) after food intake but not after fasting or feeding to satiation. Endocrinology 147: 5786-5797. http://dx.doi. org/10.1210/en.2006-0824

Kulig H and Kmieć M (2009). Association between leptin gene polymorphisms and growth traits in Limousin cattle. Genetika 45: 838-841.

Kurokawa T and Murashita K (2009). Genomic characterization of multiple leptin genes and a leptin receptor gene in the Japanese medaka, Oryzias latipes. Gen. Comp. Endocrinol. 161: 229-237. http://dx.doi.org/10.1016/j. ygcen.2009.01.008

Kurokawa T, Uji S and Suzuki T (2005). Identification of cDNA coding for a homologue to mammalian leptin from pufferfish, Takifugu rubripes. Peptides 26: 745-750. http://dx.doi.org/10.1016/j.peptides.2004.12.017

Li GG, Liang XF, Xie Q, Li G, et al. (2010). Gene structure, recombinant expression and functional characterization of grass carp leptin. Gen. Comp. Endocrinol. 166: 117-127. http://dx.doi.org/10.1016/j.ygcen.2009.10.009

Mácajová M, Lamosová D and Zeman M (2004). Role of leptin in farm animals: a review. J. Vet. Med. A Physiol. Pathol. Clin. Med. 51: 157-166. http://dx.doi.org/10.1111/j.1439-0442.2004.00619.x

Moschos S, Chan JL and Mantzoros CS (2002). Leptin and reproduction: a review. Fertil. Steril. 77: 433-444. http:// dx.doi.org/10.1016/S0015-0282(01)03010-2

Murashita K, Uji S, Yamamoto T, Rønnestad I, et al. (2008). Production of recombinant leptin and its effects on food intake in rainbow trout (Oncorhynchus mykiss). Comp. Biochem. Physiol. B Biochem. Mol. Biol. 150: 377-384. http:// dx.doi.org/10.1016/j.cbpb.2008.04.007

Özlem E and Dursun Ö (2011). An application of information theoretical measures for DNA structure. Turk. Klinikleri. J Biostat. 3: 1-7.

Pérez-Montarelo D, Fernández A, Folch JM, Pena RN, et al. (2012). Joint effects of porcine leptin and leptin receptor polymorphisms on productivity and quality traits. Anim. Genet. 43: 805-809.

Rodriguez S, Gaunt TR and Day IN (2009). Hardy-Weinberg equilibrium testing of biological ascertainment for Mendelian randomization studies. Am. J. Epidemiol. 169: 505-514. http://dx.doi.org/10.1093/aje/kwn359

Rønnestad I, Nilsen TO, Murashita K, Angotzi AR, et al. (2010). Leptin and leptin receptor genes in Atlantic salmon: Cloning, phylogeny, tissue distribution and expression correlated to long-term feeding status. Gen. Comp. Endocrinol.

Genetics and Molecular Research 15 (3): gmr.15037635 
168: 55-70. http://dx.doi.org/10.1016/j.ygcen.2010.04.010

Roubos EW, Dahmen M, Kozicz T and Xu L (2012). Leptin and the hypothalamo-pituitary-adrenal stress axis. Gen. Comp. Endocrinol. 177: 28-36. http://dx.doi.org/10.1016/j.ygcen.2012.01.009

Ryynänen HJ and Primmer CR (2006). Single nucleotide polymorphism (SNP) discovery in duplicated genomes: intronprimed exon-crossing (IPEC) as a strategy for avoiding amplification of duplicated loci in Atlantic salmon (Salmo salar) and other salmonid fishes. BMC Genomics 7: 192. http://dx.doi.org/10.1186/1471-2164-7-192

Sadeghi M, Niknafs S, Shahrbabak HM and Fatemi SA (2012). Two SNP in STAT5B gene and their association with breeding value of growth and egg production traits in Mazandaran Indigenous Chicken. Livest. Sci. 147: 198-202. http://dx.doi.org/10.1016/j.livsci.2012.04.015

Tang Y, Yu J, Li H, Xu P, et al. (2013). Molecular cloning, characterization and expression analysis of multiple leptin genes in Jian carp (Cyprinus carpio var. Jian). Comp. Biochem. Physiol. B Biochem. Mol. Biol. 166: 133-140. http:// dx.doi.org/10.1016/j.cbpb.2013.07.009

Venter JC, Adams MD, Myers EW, Li PW, et al. (2001). The sequence of the human genome. Science 291: 1304-1351. http://dx.doi.org/10.1126/science.1058040

Wei Y, Huang H, Meng Z, Zhang Y, et al. (2013). Single nucleotide polymorphisms in the leptin-a gene and associations with growth traits in the orange-spotted grouper (Epinephelus coioides). Int. J. Mol. Sci. 14: 8625-8637. http://dx.doi. org/10.3390/ijms14048625

Yang D, Chen H, Wang X, Tian Z, et al. (2007). Association of polymorphisms of leptin gene with body weight and body sizes indexes in Chinese indigenous cattle. J. Genet. Genomics 34: 400-405. http://dx.doi.org/10.1016/S1673$\underline{8527(07) 60043-5}$

Ye S, Dhillon S, Ke X, Collins AR, et al. (2001). An efficient procedure for genotyping single nucleotide polymorphisms. Nucleic. Acids Res. 29: e88-8.

Zhang HX, Chen HP, Zhang Y, Li SS, et al. (2013). Molecular cloning, characterization and expression profiles of multiple leptin genes and a leptin receptor gene in orange-spotted grouper (Epinephelus coioides). Gen. Comp. Endocrinol. 181: 295-305.

Zhang M and Bai XJ (2015). Leptin and leptin receptor gene polymorphisms are correlated with production performance in the Arctic fox. Genet. Mol. Res. 14: 5560-5570. http://dx.doi.org/10.4238/2015.May.25.7

Zhang Y, Proenca R, Maffei M, Barone M, et al. (1994). Positional cloning of the mouse obese gene and its human homologue. Nature 372: 425-432. http://dx.doi.org/10.1038/372425a0

Zuo L, Wang K and Luo X (2014). Use of diplotypes - matched haplotype pairs from homologous chromosomes - in genedisease association studies. Shanghai Arch Psychiatry 26: 165-170.

Genetics and Molecular Research 15 (3): gmr.15037635 